\title{
THE EFFECTS OF CONCENTRATE FEED AND MINERAL BLOCK ON THE DENSITY LEVEL AND MILK FAT CONTENT OF DAIRY CATTLE
}

\author{
${ }^{1}$ Desty Shafira ${ }^{2}$ Romziah Sidik, ${ }^{3}$ Mufasirin \\ ${ }^{1}$ Student of Faculty Veterinary Medicine of Universitas Airlangga \\ ${ }^{2}$ Professor in Animal Husbandry Department, Faculty Veterinary Medicine of Universitas Airlangga \\ ${ }^{3}$ Parasitology Departemen, Faculty Veterinary Medicine of Universitas Airlangga \\ E-mail : desty_shafira@yahoo.com
}

\begin{abstract}
The aim of this research is to understand the influence of concentrate feed and mineral block formulation on the densitylevel and milk fat of dairy cattle. The research was conducted on eight cross breed friesian holstein cows with \pm $450 \mathrm{~kg}$ body weight and aged 2-4 years with milk production 8-11 liter/head/day. The experimental design of this study was complete randomized design with two treatments and each treatment was repeated four times. PO (grass, tofu waste) and P1 (grass, tofu waste, concentrate feed, mineral block). The data was analyzed using $t$ test (independent sample $t$ test ). The software that was used to analyzed the data is Statistical Program for Social Science (SPSS) version 20 for Windows. The results showed that concentrate feed and mineral block did not significantly affect the density of milk and milk fat ( $p>0.05$ ). The mean density of milk in the PO was 1.0255 and $P 1$ was 1.0253. Mean while the average milk fat in the PO was $3.27 \%$ and in P1 was $3.45 \%$.
\end{abstract}

Keywords : concentrate, mineral block, density, fat, dairy cow

\section{INTRODUCTION}

Dairy needs consumed by the people of Indonesia, making dairy farmers duties are importantly considered in raising dairy cattle to produce quality cow's milk products for consumption by the people. Giving animal feed and good feed management in the form of forage and concentrate is an effort to increase milk production (Sidik, 2004).

The problems that often occur are low dairy productivity, and the quality of milk produced does not meet the milk processing industry standards. Livestock that lack of feed, especially dairy cattle will result in decreased production, health status, and also adversely affect reproduction (Saptahidayat, 2005). According to Basya (1983), milk fat content is influenced by the main factors, namely rations given and local climate conditions.

Feed given for dairy cattle there are two kinds of feed, raw material forage feed and reinforcing feed material in the form of concentrate (Frias, 2015). The addition of mineral blocks aims to supplement the micro elements such as minerals and vitamins so that they are able to achieve high milk productivity (Prasetyono, 2014). According to Sudono (2003) and Ramelan (2001), concentrate is more influential on the milk density and as an additional feed that can complement the requirement of the main food substances such as protein and fat that have not been met only from forage. So it is expected to be one solution in the improvement livestock productivity.

Based on this background, improving the quality of feed with the addition of concentrates and mineral blocks hopefully makes a more balanced nutritional content so that it can meet the physiological needs of livestock for nutrition during lactation.
The purpose of the research is to observe the effects of giving formulation concentrate and mineral block to milk density and milk fat dairy cattle.

\section{METHODS}

Animals used in this study were Friesian Holstein (PFH) with the total of 8 cattle in lactation period aged 2-4 years. This study consists of two stages, namely the preparation stage and the experimental stage. Preparation stage was done for one week for feed adaptation and experimental stage was done in one week for trial stage and data collection.

The amount of feed on treatment PO consisted of forage with as much as $\pm 30 \mathrm{~kg} /$ head / day and tofu waste product of $\pm 32 \mathrm{~kg}$ / head / day as provided by the dairy cattle farmer. The amount of feed on treatment P1 consists of forage of $10 \%$ of cow body weight or about $\pm 45 \mathrm{~kg} /$ head / day. Each cattle P1 group received $4 \mathrm{~kg}$ of concentrate /head/day and mineral block $50 \mathrm{~g} /$ day.

Data obtained in the study were analyzed by $t$ test (independent sample t test). The software used for data analysis is Statistical Program for Social Science (SPSS) version 20 for Windows.

\section{RESULTS}

Milk Density

The results obtained on the basis of $t$ test (independent sample $t$ test) showed that concentrate feed and mineral of block did not showed significant difference $(p>0.05)$ with tofu waste product to density of milk. Density on feed treatment P0 1.0255 was not significantly different with feed treatment P1 1,0253. The result of weight data of milk type can be seen in Table 1. 
Table 1. Average and Standard Deviation of Weight Type of Milk for 7 days.

\begin{tabular}{|l|l|}
\hline Treatment & Density \\
\hline P0 & $1.0255^{\mathrm{a}} \pm 0.0018$ \\
\hline P1 & $1.0253^{\mathrm{a}} \pm 0.0026$ \\
\hline
\end{tabular}

Description: Superscript on the same line shows no significant difference between treat $(p>0.05)$.

\section{Milk Fat Content}

The results obtained by $t$ test (independent sample $\mathrm{t}$ test) showed that concentrate feed and mineral formulation block did not showed any significant difference with tofu waste product for cow milk fat $(p>0.05)$. Fat content in feed treatment P0 (3.27) was not significantly different with feed treatment P1 (3.45). The result of milk fat content can be seen in Table 2.

Table 2. Average and Standard Deviation of Milk Fat Content for 7 days.

\begin{tabular}{|l|l|}
\hline Treatment & Milk Fat \\
\hline P0 & $3,27^{\mathrm{a}} \pm 0,74$ \\
\hline P1 & $3,45^{\mathrm{a}} \pm 1,16$ \\
\hline
\end{tabular}

Description: Superscript on the same line shows no significant difference between treat ( $p>$ $0,05)$

\section{DISCUSSION}

The result of the density value for PO was higher than P1 treatment although it does not give any significant differences, it can be caused by the decrease of fat content in the treatment of PO. The results are supported by the statement of Legowo (2002) that the content of milk fat affect the density of milk, if the milk fat content shows a high value then the density value is low and if the milk fat content shows a low value then the density value is high because the density of fat is lower than density of water or milk plasma, that is 0.93 .

The results of density on the feed combination of $\mathrm{P} 1$ were not significantly different from $P 0$. This can be due to the quantity of forage given to $\mathrm{P} 1$ which is more than the treatment of PO with as much as $45 \mathrm{~kg}$ which contains more crude fiber consumed by cow. Meanwhile, based on the results of the proximate analysis of the tofu waste product and formulated concentrate, the formulated concentrate contained higher crude fiber (9.08\%) that is higher than the tofu waste product that makes the Neutral Detergent Fiber (NDF) contained in crude fiber forage and higher formulation concentrates resulted in the increased of fat content and effect on the weight content of milk (Pangestu et al., 2003).

In this research, the density value contained in milk is lower than the standard weight type set by the Indonesian National Standard (SNI) at least 1.0280.

According to Basya (1983), milk fat content is influenced by several factors: 1) lactation level, early lactation cow will have high milk fat content, but will decrease and increase at the end of lactation, 2) milking intervention, milk fat content on the Evening is higher than the fat content of milk in the morning, 3) Age of cattle, in the first lactation until the age of 6-8 years the production increased and after that age the production decreased, 4) Climate, the cold climate of milk fat is higher, 5) Types of dairy cattle, Friesian Holstein has high dairy producing ability and low fat content, 6) Ration, ration with low crude fiber causes decreased milk fat content.

The highest value of fat content was found in P1 treatment because of the concentrate and mineral block concentration in feed. Based on the result of the proximate analysis, the formulated and tofu-based concentrate samples in the freeze-dried material, the crude fiber value of concentrate formula was higher compared to the tofu waste. Differences in the content of crude fiber obtained from milk fat content in cows who were given a higher formulation concentrate than cattle fed with tofu waste product. This is in accordance with the opinion of Maheswari (2004), which states that the content of milk fat in dairy cattle depends on the content of crude fiber in the feed. The higher the crude fiber contained in the feed, the higher the fat content in milk.

Folley (1998), also states that the presence of high crude fibers in the feed will produce high amounts of acetic acid in the rumen. Feed with high crude fiber content will result in a high fat content because the crude fibers will be fermented by microbes in the rumen to VFA in the form of acetic acid (Schor and Gagliastro, 2001). Where acetic acid is used to synthesize fatty acids.

Mineral block also did not make any significant differences to the density of milk, but the needs of mineral block for lactating dairy cattle is absolutely necessary, although given in small amounts (Underwood, 1982; Paiq, 2001). The essential macrominerals for livestock are $\mathrm{Ca}, \mathrm{P}, \mathrm{Mg}, \mathrm{K}, \mathrm{Na}$, S while microminerals are $\mathrm{Zn}, \mathrm{Cu}, \mathrm{Fe}, \mathrm{Mn}, \mathrm{Se}, \mathrm{Co}$, and Mo which play an important role in the metabolism and physiology of livestock (Underwood, 1981).

\section{CONCLUSION}

1) Feeding of concentrate and mineral formulation block did not make any difference to density of dairy cattle.

2) Feeding of concentrate and mineral formulation block did not give any difference to milk fat content of dairy cattle. 


\section{REFERENCES}

Basya, Sori. 1983. Berbagai Faktor Yang Mempengaruhi Kadar Lemak Susu Sapi Perah. Balai Penelitian Ternak. Bogor.

Frias, B. 2015. Pemberian Konsentrat Dengan Penambahan Kulit Ubi Kayu Untuk Meningkatkan Produksi Susu Sapi Perah Di Kelompok Tani Ternak Tunas Baru Padang Panjang. [Skripsi]. Fakultas Peternakan. Politeknik Pertanian Negeri Payakumbuh. http://repository.politanipyk.ac.id/302/4/ISITA.pdf [25 Januari 2017].

Legowo, A.M. 2002. Sifat Kimiawi, Fisik, Mikrobiologis Susu. Diktat Program Studi Teknologi Hasil Ternak. Fakultas Peternakan Universitas Diponegoro. Semarang Murtidjo, B. A. 1987. Pedoman Meramu Pakan Unggas. Cetakan ke-1. Kanisius. Jakarta.

Maheswari, R. R. A. 2004. Penanganan dan Pengolahan Hasil Ternak Perah. Institut Pertanian Bogor. Bogor.
Pangestu, E. T. Toharmat., U.H. Tanuwiria. 2003. Kajian Kadar Lemak dan Bahan Kering Tanpa Lemak Susu Kambing Sapera di Cilacap Bogor. J. Anim. Sci. 1(3) : 874-880.

Ramelan. 2001. Efisiensi Produksi pada Sapi perah Dara dan Laktasi Akibat Penyuntikan PMSG. [Skripsi]. Fakultas Peternakan. Universitas Diponegoro.

Saptahidayat, N. 2005. Manajemen Pakan Sapi Perah. Edisi Februari 2005. Poultry Indonesia. 64-65.

Schor, A., and G.A. Gagloistrof. 2001. Undergradble Protein Suplementation To Early Lactation Dairy Cows In Grazing Condition. J. Dairy Sci. 84: 15971606.

Sidik, R. 2004. Komoditas dan Bangsa Ternak Perah Sub Bagian Produksi Ternak. Fakutas Kedokteran Hewan Universitas Airlangga. Surabaya.

Sudono, Adi., R.F. Rosdiana., B.S. Setiawan. 2003. Beternak Sapi Perah Secara Intensif. Agromedis Pustaka. Jakarta. 29. 